\title{
Sedimentologic and volcanologic investigation of the deep Tyrrhenian Sea: preliminary results of cruise VST02
}

\author{
Fabiano Gamberi $\left({ }^{1}\right)$, Michael Marani $\left({ }^{1}\right)$, Vladimiro Landuzzi $\left({ }^{1}\right)$, Angelo Magagnoli $\left({ }^{1}\right)$, \\ Daniela Penitenti $\left({ }^{1}\right)$, Mauro Rosi $\left({ }^{2}\right)$, Antonella Bertagnini $\left({ }^{2}\right)$ and Alessio Di Roberto $\left({ }^{2}\right)$ \\ (') Istituto di Scienze Marine (ISMAR), CNR, Sezione di Geologia Marina, Bologna, Italy \\ ${ }^{2}{ }^{2}$ Dipartimento di Scienze della Terra, Università degli Studi di Pisa, Italy \\ $\left(^{3}\right)$ Istituto Nazionale di Geofisica e Vulcanologia, Sede di Pisa, Italy
}

\begin{abstract}
The VST02 cruise carried out in the summer of 2002 focused on sedimentologic and volcanologic research over selected areas of the deep portion of the Tyrrhenian Sea. Chirp lines and seafloor samples were collected from the Calabrian slope surrounding Stromboli Island, in the Marsili deep-sea fan, in the Vavilov Basin and in the Vavilov seamount. Submarine volcanic activity, both explosive and effusive, is occurring in the Stromboli edifice. Explosive submarine volcanism also affects the shallowest areas of the Vavilov seamount. Submarine carbonate lithification has been observed on the sediment-starved flanks of the Vavilov seamount. Acoustic transparent layers make up the recentmost infill of the Gortani Basin, the easternmost portion of the Vavilov Basin. Channels comprised of a variety of architectural elements and depositional lobes are the main elements of the Marsili deep-sea fan where, apparently, sedimentation occurs mainly through debris flow processes.
\end{abstract}

Key words submarine volcanism - submarine volcanic explosions - deep-sea fan - acoustic transparent layers - carbonate crusts

\section{Intoduction}

The VST02 cruise, carried out on board the R/V Urania from 29 August to 19 September 2002, focused on the study of sedimentologic and volcanologic issues through the investigation of selected areas in the southeastern and central portion of the Tyrrhenian Sea (fig. 1).

In the Southestern Tyrrhenian Sea, the cruise investigated the slopes that surround the vol-

Mailing address: Dr. Fabiano Gamberi, Istituto di Scienze Marine (ISMAR), CNR, Sezione di Geologia Marina, Via Gobetti 101, 40129 Bologna, Italy; e-mail: fabiano.gamberi@ismar.cnr.it canic Stromboli Island, the Stromboli sea valley and the eastern portion of the Marsili Basin. The aim of the research was the detailed study, through the acquisition of high resolution seismic data and seafloor samples, of the architectural elements and the sedimentary facies of the eastern portion of the Stromboli valley and of the Marsili Basin. A further related target was to test whether the deep submarine areas around Stromboli Island could contribute to the study of the evolution of the Stromboli volcano, with particular reference to its explosive eruptions and collapse events. An additional objective was the characterization of a seamount (Casoni seamount) located southwest of Stromboli Island at a water depth of around $1000 \mathrm{~m}$.

In the Central Tyrrhenian Sea, the cruise focused on the study of the Vavilov Basin and the homonymous volcanic seamount that sits in its centre. Dredging was carried out on the summit and flanks of the Vavilov edifice to obtain sam- 


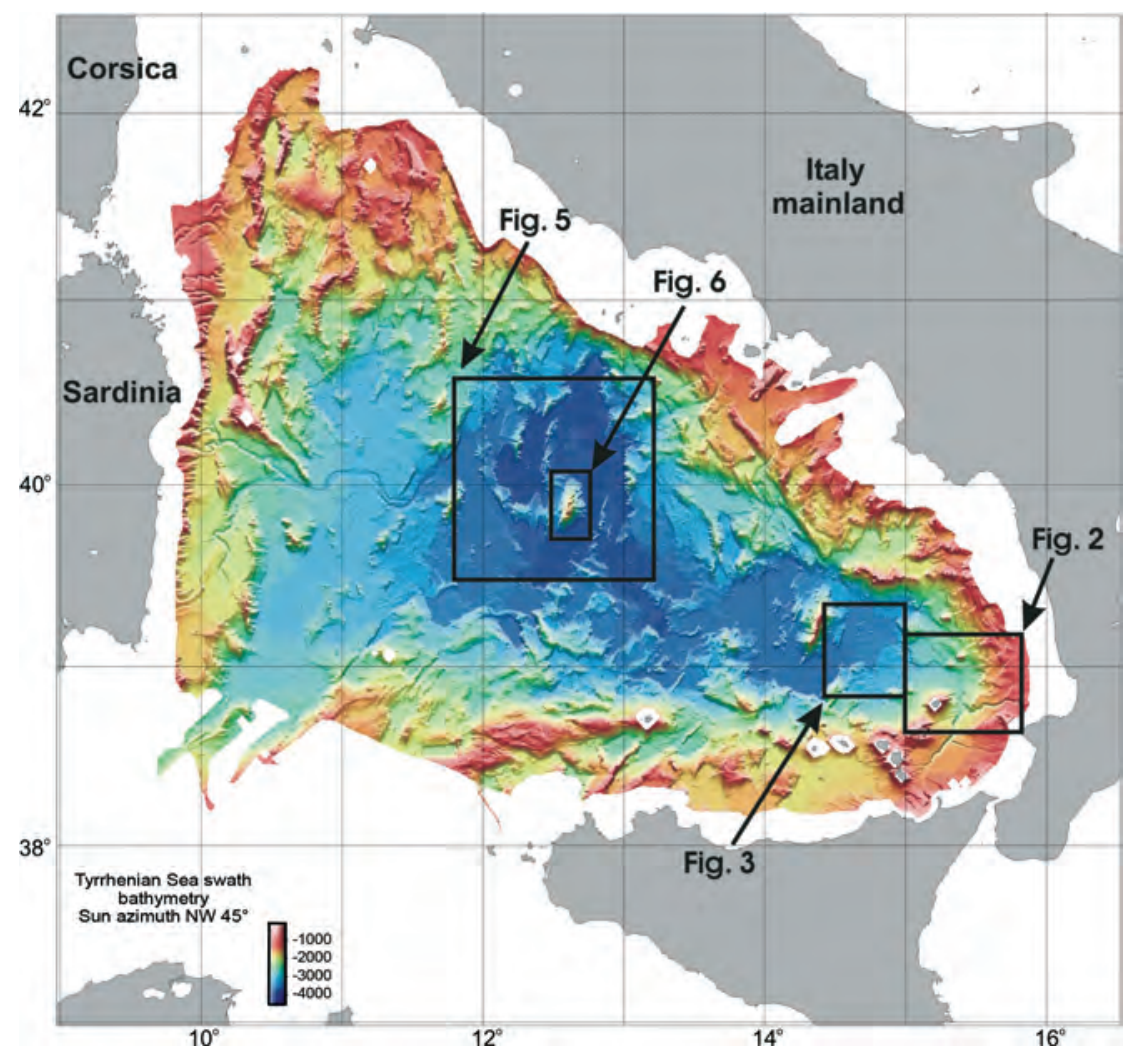

Fig. 1. Colour-shaded bathymetric map of the Tyrrhenian Sea. The areas targeted by the investigations carried out during the VST02 (boxes) are detailed in the subsequent figures.

ples from the different volcanic elements that compose the seamount. The expected result, through geochemical study of lava samples, is the framing of the Vavilov seamount volcanism in the geodynamic evolution of the Tyrrhenian Sea. In addition, high resolution seismic lines and gravity-core samples were collected in the Vavilov abyssal plain with the aim of deciphering the processes that contribute to its recent sedimentary infill.

This paper reports the details of the cruise aims and strategy and the location of the sampling sites and of the Chirp lines. In addition, the description and interpretation of the acquired data, as deduced by on board observations, are illustrated together with a presentation of the preliminary results.

\section{Cruise strategy: geophysical data acquisition and sampling equipment}

The research topics, the relevant areas to investigate during the cruise, the techniques of data acquisition and the research methodology were mainly planned on the basis of a preparatory interpretation of multibeam echosounder bathymetric data (fig. 1), deep-towed sidescan sonar images and seismic lines already available at the ISMAR. During this preliminary work, new sedimentary and volcanic elements, such as the Marsili deep-sea fan, a seamount in the southern slope of Stromboli, the individual volcanic building blocks that make up the Vavilov seamount were recognized for the first time. In addition, further details of other, al- 
ready known seafloor features were revealed and used to plan the VST02 cruise.

The aims of the cruise were fulfilled through the acquisition of high-resolution seismic lines and seafloor samples.

Chirp lines were collected during night time. The chirp signal was in the low frequency, $\mathrm{CH} 1$ band $(2-7 \mathrm{kHz})$. The resulting data were plotted in real time with an EPC9800 and acquired in SEG-Y format on magneto optical disks. The high resolution seismic data were aquired with the twofold aim of defining the depositional elements of the studied area, one of the main targets of the research, and of selecting the sampling sites to characterize their distinctive sedimentary facies.

Sampling operations were carried out through dredging, gravity coring and box coring. Dredging with a conventional, cylindrical, iron-chained, toothed dredge was performed in the areas of supposed rocky seafloor, namely on the Vavilov seamount and on the Casoni seamount south of Stromboli Island. A $1300 \mathrm{~kg}$ gravity corer was utilized in sedimented areas; the core tube length determining the maximum recoverable length, was selected on the basis of the presumed sediment texture. Only a few of the cores were opened and described on board. In areas where gravity coring did not allow any recovery, due to coarse-grained sediments at the seafloor, a box corer was utilized; it allowed the recovery of samples with a diameter of $32 \mathrm{~cm}$, with a maximum recovery of $50 \mathrm{~cm}$ deep sections. The samples collected through box coring were described on board and subsample cores were obtained for further laboratory analysis.

\section{Calabrian and Stromboli slopes, Stromboli valley and Marsili Basin (figs. 2, 3)}

\subsection{Geological setting and aims of investigation}

Stromboli Island is the northernmost subaerial volcanic edifice of the Aeolian Islands

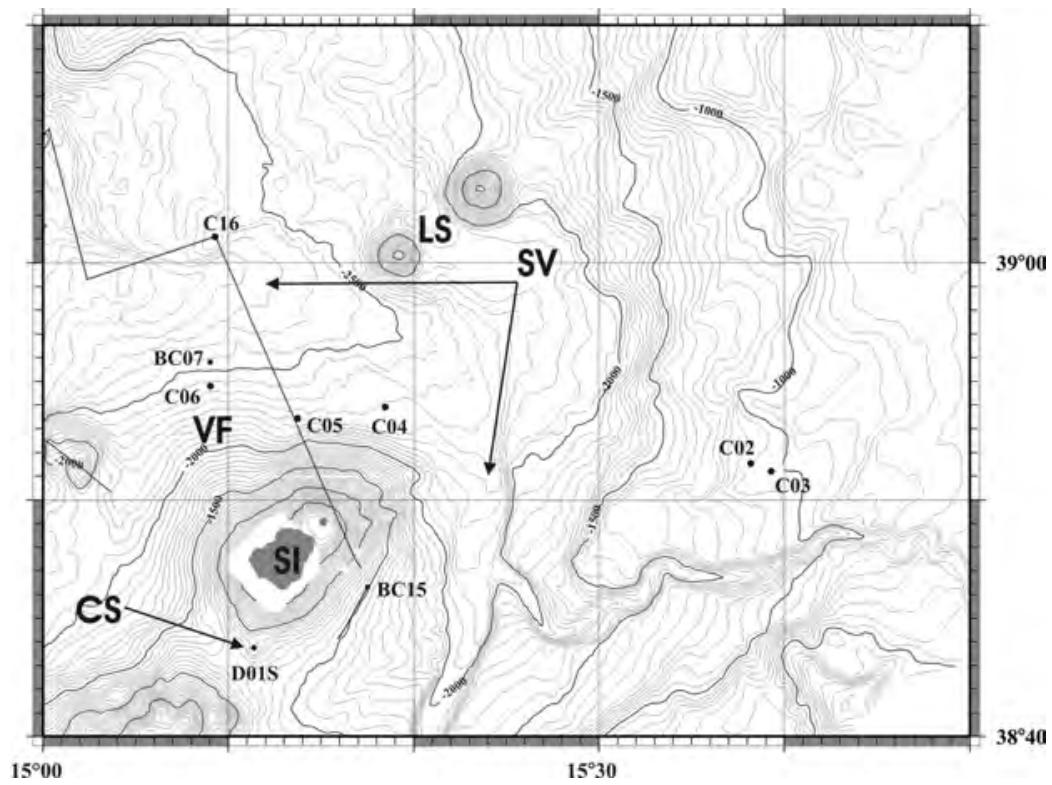

Fig. 2. Traces of Chirp profiles (thin lines) and location and number of seafloor samples (circles = gravity cores; squares $=$ box cores; rhombs $=$ dredgings) in the area surrounding Stromboli Island (SI - Stromboli Island; LS - Lametini Seamounts; SV - Stromboli Valley; VF - Volcaniclastic Fan facing the Sciara del Fuoco; CS - Casoni Seamount). 


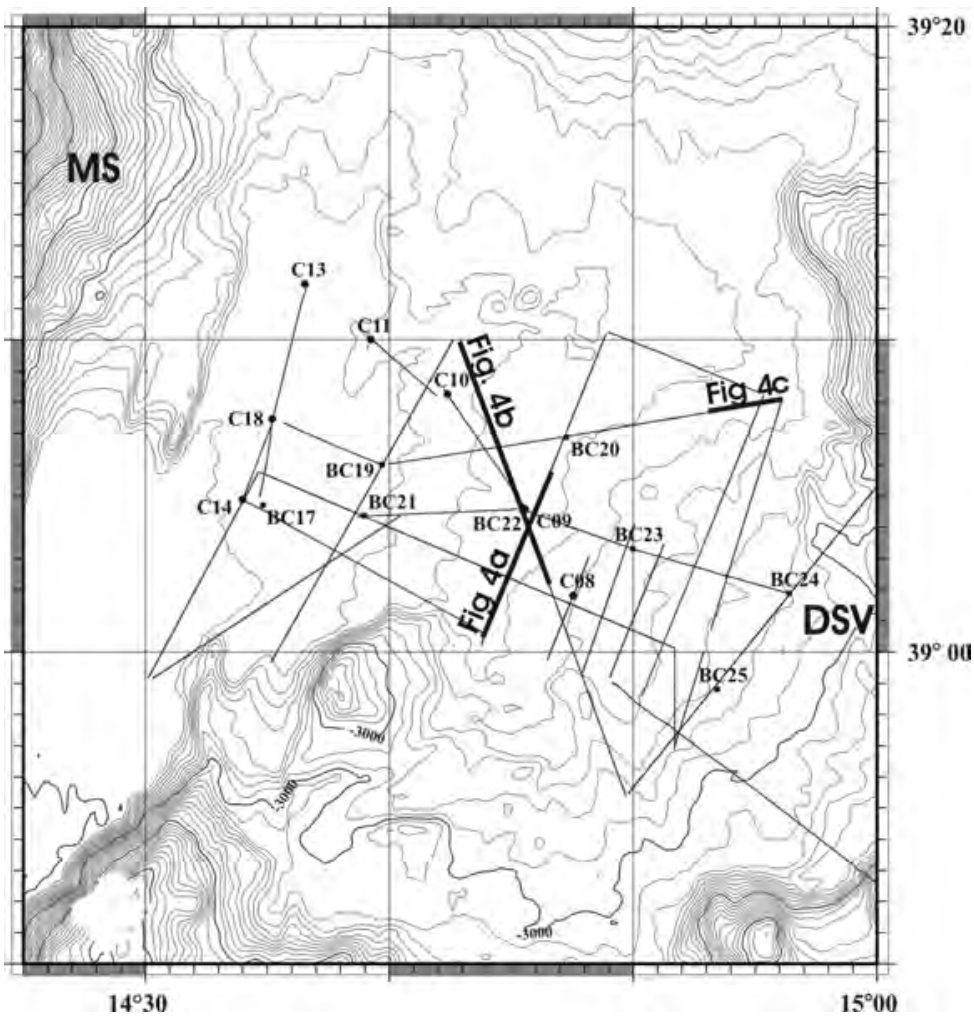

Fig. 3. Traces of Chirp profiles (thin lines) and location and number of seafloor samples (symbols as in fig. 2) collected in the Eastern Marsili Basin. Bold lines correspond to the line segments shown in fig. 4a-c. (DSV Distal part of the Stromboli Valley; MS - Marsili Seamount).

Arc. Its base, lying at a water depth of around $3000 \mathrm{~m}$ to the north, shallows toward the south in the area that connects the submarine portions of the Stromboli and Panarea edifices, where two seamounts sit at a depth of 700 and $1000 \mathrm{~m}$, respectively (fig. 2). The shallowest seamount, named Cavoni, was already known and sampled (Gabbianelli et al., 1993). No data were available for the deepest one, that we informally called Casoni seamount (CS in fig. 2), a target of the VST02 cruise.

A further target was that of sampling tephra layers due to the activity of Stromboli volcano. The stratigraphy of the volcanic products of Stromboli Island is well established (HornigKiarsgaard et al., 1993) and high resolution studies that outline its recent $(<2000$ years $)$ eruptive style, with particular emphasis on explosive activity, are available (Rosi et al., 2000). Research on the Reunion Island volcano have, however, disclosed that the study of submarine cores, due to a potential of tephra preservation in the deep marine environment higher than on land, can provide a refined stratigraphy of explosive events (Fretzdorff et al., 2000). With this in mind, one of the aims of the cruise was that of collecting cores in selected, undisturbed seafloor sites in order to establish a correlation between marine and on-land tephrostratigraphic records.

The submarine flanks of the Stromboli edifice are the sites of predominantly volcaniclastic deposition. In particular, a volcaniclastic fan is developed in the area facing the Sciara del 
Fuoco (VF in fig. 2), where the present-day activity of the Stromboli volcano results in abundant volcaniclastic debris entering the sea (Kokeelar and Romagnoli, 1995; Gamberi et al., 2002). The composition, distribution and facies variations of volcaniclastic deposits in the submarine environment adjacent to island arcs reflect the complex interplay between the tectonic evolution of the arc and the surrounding basins, the rate and type of volcanic activity and the nature of the transporting processes (Carey, 2000). In particular, when accurate sedimentologic and geochemical studies of volcaniclastic deposits are carried out, it is possible to discriminate between primary syn-eruptive deposits that are directly related to submarine or subaerial pyroclastic flows and secondary deposits, that, on the contrary, result from multiphase reworking (Schneider, 2001). In addition, the marine environment, being the ultimate depositional site of landslides and related sediment-gravity flows, can be the best repository of information about collapse events. This implies that the deep-sea depositional systems surrounding Stromboli Island can constitute a good archive of information concerning the recent history of the volcano. Hence, the areas surrounding Stromboli Island and of the Marsili Basin were sampled with the purpose of assessing, through sedimentologic and geochemical studies, the signature of collapses and eventual, related explosions that have characterized the history of Stromboli volcano (Bertagnini and Landi, 1996; Tibaldi, 2001).

Finally, the cruise aimed at investigating the eastern portion of the Marsili Basin. The western and northern base of the Stromboli edifice is circled by the Stromboli valley (SV in fig. 2), a main morphologic feature that nucleates in the axis of the Gioia forearc basin and crosses the Aeolian volcanic arc between the Stromboli edifice and Lametini seamounts (LS in fig. 2). At a depth of around $3000 \mathrm{~m}$, along a steep escarpment that marks the western boundary of the Calabrian margin slope, the Stromboli canyon enters the eastern part of the Marsili back-arc basin (DSV in fig. 3). On the basis of multibeam data, a deep-sea fan characterized by downslope convex contours and scoured by channels down to its distal part, located at the base of the Marsili seamount (MS in fig. 3), has been recognized (fig. 3). The fan is around 40 $\mathrm{km}$ long and around $20 \mathrm{~km}$ wide. It is presumably fed by coarse-grained deposits, representing a modern analogue of small-sized sand-rich fans that are among the most important hydrocarbon reservoirs in the world (Weimer, 2004). The recently increasing efforts for exploration of deep-water clastic depositional systems require predictive geological models that much rely on the outcomings from researches on present-day analogues. The detailed study of the Marsili fan was, therefore, undertaken to define its architectural elements and their sedimentary facies with the aim of contributing to the characterization of similar, ancient depositional systems.

\subsection{Chirp profiling}

Three Chirp lines were acquired over the EW trending sector of Stromboli valley north of the Stromboli Island (fig. 2). They show that the volcaniclastic fan that develops in the area facing the Sciara del Fuoco, progradated over the Stromboli valley floor. At a depth of around $3000 \mathrm{~m}$, the Stomboli valley loses much of its relief and gives way to various channels that represent the feeding elements of the Marsili Basin deep-sea fan, which is the target of the majority of the seismic lines acquired over the southeastern study area. Seven regional transverse lines, tied by 4 longitudinal composite transects, were collected (fig. 3); Chirp data furnish a complete coverage of the Marsili deep-sea fan from a depth of around $3000 \mathrm{~m}$ to its distal, western part at the base of the Marsili seamount. Three segments of the lines are presented in fig. 4a-c. Much of the fan is characterized by a strongly reflective, rough sea-bottom suggesting that it is mainly floored by coarse-grained sandy or gravelly material and highly disorganized depositional bodies with poor lateral continuity. The different architectural elements that characterize the deep-sea fan can be recognized in the seismic lines. Three main channels run on the surface of the fan and die out at contrasting water depth, the central one (fig. 4a) reaching the deepest por- 

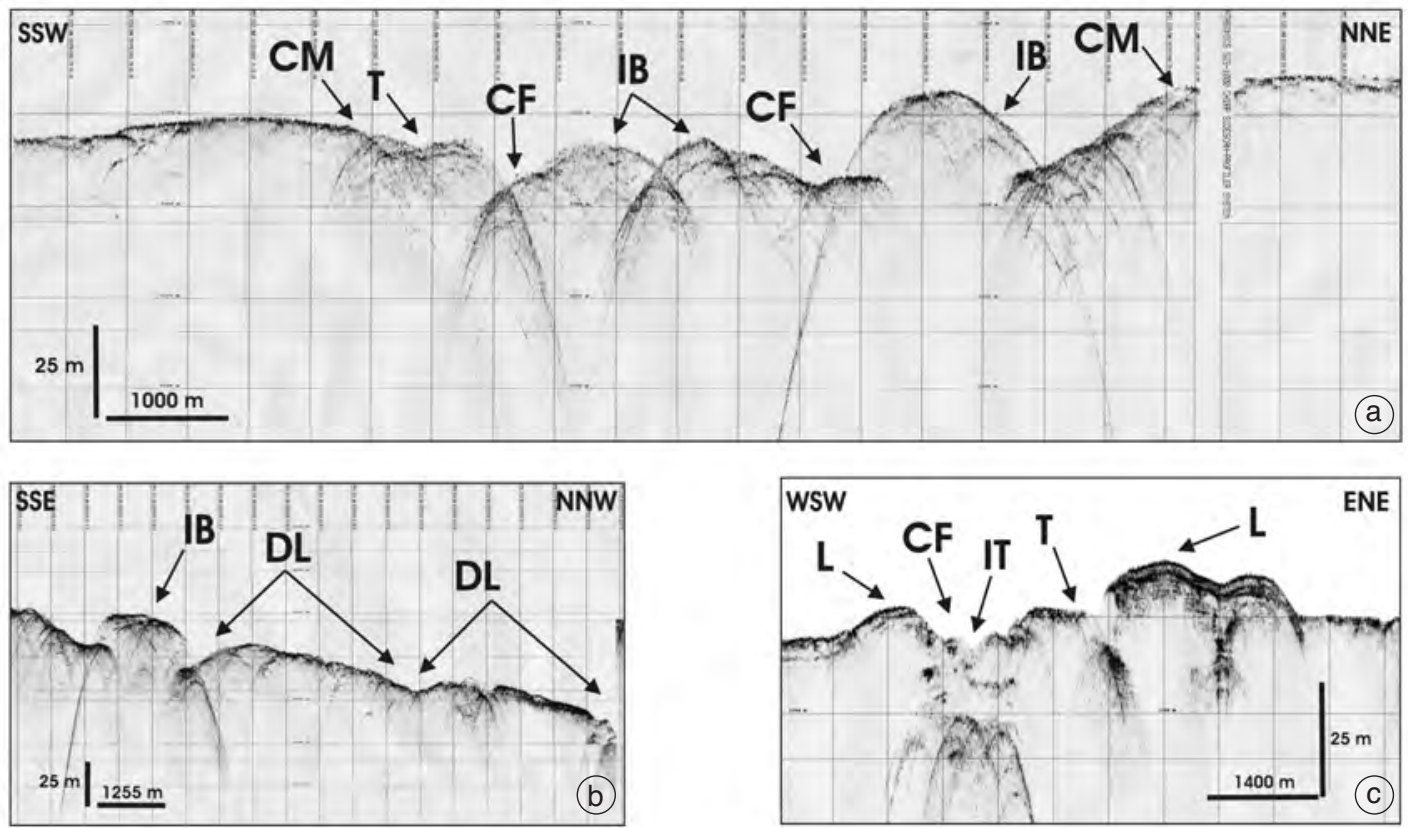

Fig. 4a-c. a) Chirp line crossing the central channel of the Marsili fan (CM - Channel Margin; $\mathrm{CF}$ - Channel Floor; IB - Intra-channel Bar; T- Terrace). b) Chirp line crossing two Depositional Lobes (DL) of the Marsili fan that are flanked by a channel with an Intrachannel longitudinal Bar (IB). c) Chirp line crossing the northernmost channel of the Marsili fan ( $\mathrm{L}$ - Levee; CF - Channel Floor; IT - Inner Thalweg; T - Terrace).

tion of the basin. Terraces, intra-channel bars, inner thalwegs and depositional levees with evidence of sediment waves and seafloor instability are common elements of the channels (fig. 4a-c). The channels gradually lose relief downslope; at their mouth, upward convex, up to 10 $\mathrm{km}$ long and $4 \mathrm{~km}$ wide depositional bodies are developed and can be interpreted as depositional lobes (fig. 4b). In some cases, smaller scale (1 km large 2-3 m thick), lenticular acoustic transparent bodies are present on the surface of the lobes and can represent the single depositional units that make up the lobes (fig. 4c).

\subsection{Seafloor sampling (figs. 2, 3)}

Two cores ( $\mathrm{C} 02$ and $\mathrm{C} 03$ ) were retrieved from the Calabrian margin, (fig. 2) in sites located away from the main sedimentary pathways and downwind from the main prevailing winds. These sites are thought to have the best potential for the preservation of tephra layers derived from the explosive activity of Stromboli volcano (fig. 2). These cores mainly consist of a hemipelagic succession but preliminary analysis has disclosed that thin tephra layers are indeed present at various levels along the sedimentary succession. In addition, frequent discontinuous patches representing remnants of tephra layers reworked by the intense bioturbation that characterizes much of the section, have been observed. In the southern slope of the Stromboli edifice (BC15; fig. 2), the recovery of rounded volcaniclastic gravels, similar to those outcropping on the beaches of the island, has shown that the Stromboli submarine flank is here floored by the deposits of sedimentgravity flows that transfer coarse-grained material down-slope from the shore source.

Four gravity and one box cores were collected in the distal portion of volcaniclastic fan 
that faces the Sciara del Fuoco and in the marginal areas of the Stromboli valley north of Stromboli Island (fig. 2). Two gravity cores (C06 and C05) did not recover sediment, likely evidence of hard or very coarse sea-bottom. The recovery of $40 \mathrm{~cm}$ of massive coarse sands (box core BC07), and of alternating sandy and silty layers (core C04) indicates that the main sedimentation style is represented by coarsegrained sediment-gravity flows. The $\mathrm{C} 16$ site was located directly to the north of the Sciara del Fuoco volcaniclastic fan, around $200 \mathrm{~m}$ above the Stromboli valley floor (fig. 2). This site was chosen with the aim of sampling a peculiar type of deposit related only to sedimentgravity flows originated from the slope of the Stromboli edifice and capable of overriding the Stromboli valley margin. The recovery of a thick layer of black volcaniclastic sand with abundant glass fragments whose origin is tentatively ascribed to Stromboli volcano, suggests that this kind of flows do occur and poses important hints on their genetic processes.

In order to characterize the sedimentary facies of the distinct architectural elements recognized through the interpretation of the chirp lines in the Marsili fan, 7 gravity and 8 box cores were obtained from the eastern portion of Marsili Basin (fig. 3). Box cores BC24 and $\mathrm{BC} 25$ have revealed that the proximal parts of the channels that feed the Marsili fan are floored by a coarse-grained seafloor with cross-stratified layers of gravel-sized pumice and quartz grains. C08 gravity core was successful in recovering around $80 \mathrm{~cm}$ of massive sand from the middle portion of the fan; $\mathrm{C} 10$ and $\mathrm{C} 09$ did not recover sediment. As a consequence, sampling of this area was mainly accomplished through box coring (BC23, BC22, BC20, BC19, BC21, $\mathrm{BC} 17)$ collected in the distal portion of the channels, in the longitudinal bars, and in the lobes. The recovered sediments mainly consist of poorly sorted muddy sands with abundant floating mud clasts (with dimensions up to more than $10 \mathrm{~cm}$ ) interpreted as the result of debris flow processes. Well sorted sandy layers with evidence of traction, likely resulting from turbidity currents, were also found. Gravity coring was more successful in the distal part of the fan with recovery of respectively $5.25 \mathrm{~m}(\mathrm{C} 13), 3.31$
$\mathrm{m}(\mathrm{C} 11)$ and $0.90 \mathrm{~m}(\mathrm{C} 14)$ while no recovery was achieved by core $\mathrm{C} 18$.

We dredged (D01) the southern flank of the Stromboli edifice to verify the nature of the $\mathrm{Ca}$ soni seamount, located to the southwest of the Stromboli Island at around $1000 \mathrm{~m}$ depth (CS in fig. 2). Beside fresh lava samples, various pieces of decimeter-size glassy vescicular material were recovered embedded in mud and interpreted as volcanic scoriae produced by submarine explosive activity. The freshness of the samples indicate a very recent volcanic activity and, more interestingly, the lava samples were warm when taken on board.

\section{Vavilov Basin and seamount}

\subsection{Geological setting and aims of investigations}

The Vavilov Basin is thought to be the oldest area floored by oceanic crust in the Tyrrhenian Sea (Kastens and Mascle, 1990). It has a mean depth of around $3500 \mathrm{~m}$ and the homonymous seamount rises at its center. The Vavilov Basin is bounded by several structural ridges with variable heights above the basin floor. In addition, the D'Ancona ridge and the Vavilov seamount separate the Vavilov Basin into the Gortani and Magnaghi basins (fig. 5). The Gortani ridge, connected to the south to the Vavilov seamount, lies in the central portion of the Gortani Basin (fig. 5). The Chirp seismic facies of the recent infill of the northern portion of the Gortani Basin (fig. 5) was calibrated by three gravity cores.

The Vavilov seamount is $33 \mathrm{~km}$ long and 17 $\mathrm{km}$ wide, with a relief of $c a .2700 \mathrm{~m}$. Its base lies at depth variable between $3500 \mathrm{~m}$, to the east and 3200 , to the west, while its highest peak is at around $800 \mathrm{~m}$. A peculiar feature of the volcano is a strong asymmetry with a steep, smooth western side and a more gently sloping and more rough eastern flank. Few lava samples were recovered from the Vavilov seamount before cruise VST02 (Selli et al., 1977; Robin et al., 1987; Savelli, 1988); an extensive sampling of the different elements recognized on the basis of mutibeam bathymetric maps of the volcano was therefore undertaken (fig. 6). Circular features, with dimensions up to $1 \mathrm{~km}$ in width and $200 \mathrm{~m}$ in height, are pres- 

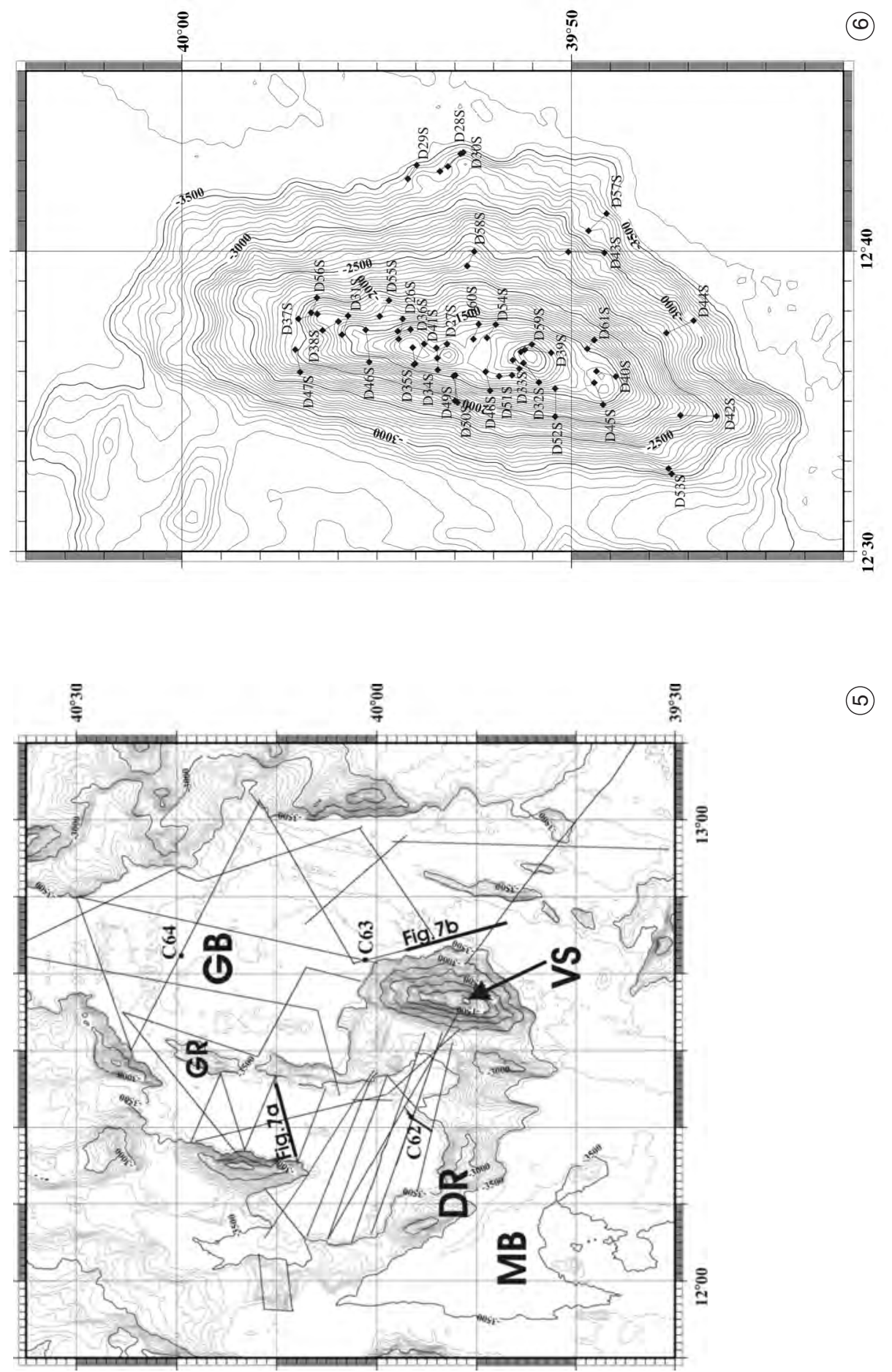

(1)

哭苞

㕸

贾艺

음

空

$>$

\& $\cong$

강

ำ

¿

동

ङ

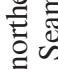

흘

항

ต

E $>$

吾.

覀

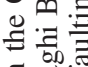

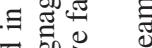

욜

议

نे

एँ

ठำ

उ료

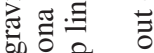

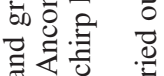

के छ

光荅

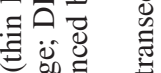

us :

능

흔

3.

키류

t垈

离密

的管

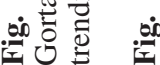


ent on the distal volcano flanks, particularly to the east. These features have been interpreted as single volcanic centres and were one of the targets of the seafloor sampling. The majority of the sampling sites were however located on the uppermost part of the volcano. Here numerous dredges were carried out with the aim of recovering samples from the elongated culminations and the intervening saddles that compose the NNE-SSW trending axial portion of the volcano.

\subsection{Chirp profiling}

Around 450 nautical miles of Chirp high-resolution seismic profiles were acquired in the Gortani Basin (fig. 5), achieving the penetration of around $60 \mathrm{~m}$ of subbottom sediments. As shown by the two lines in fig. 7a,b, the prominent features of the seismic lines are 4 acoustic transparent layers (ATLs). The deepest ATL (DATL) has a thickness of $c a .25 \mathrm{~m}$ and its base, lying at a depth between 50 and $60 \mathrm{~m}$, coincides generally with the penetration limit of the seis- mic energy (fig. 7a,b). An intermediate ATL (IATL) with a thickness of around $15 \mathrm{~m}$ directly overlies the DATL or a thin discontinuous reflective package that is sometimes present on top of the DATL. Both the deepest and the intermediate ATLs are recognized throughout the basin although thickness variations are especially evident approaching the basin bounding highs. The two topmost ATLs (UATLs) are separated from the intermediate ATL by a thick, well reflective sequence. They pinch out considerably toward the Gortani seamount and stretch across two distinct depocenters in the eastern and western portion of the Gortani Basin, respectively. Active faulting is evident in the chirp lines, resulting in seafloor steps; faults have a NNE-SSW trend corresponding to the lineaments in the bathymetric map in the basin floor (fig. 5).

\subsection{Seafloor sampling}

Three sites were dredged on the eastern base of the volcanic edifice at depths between 3500
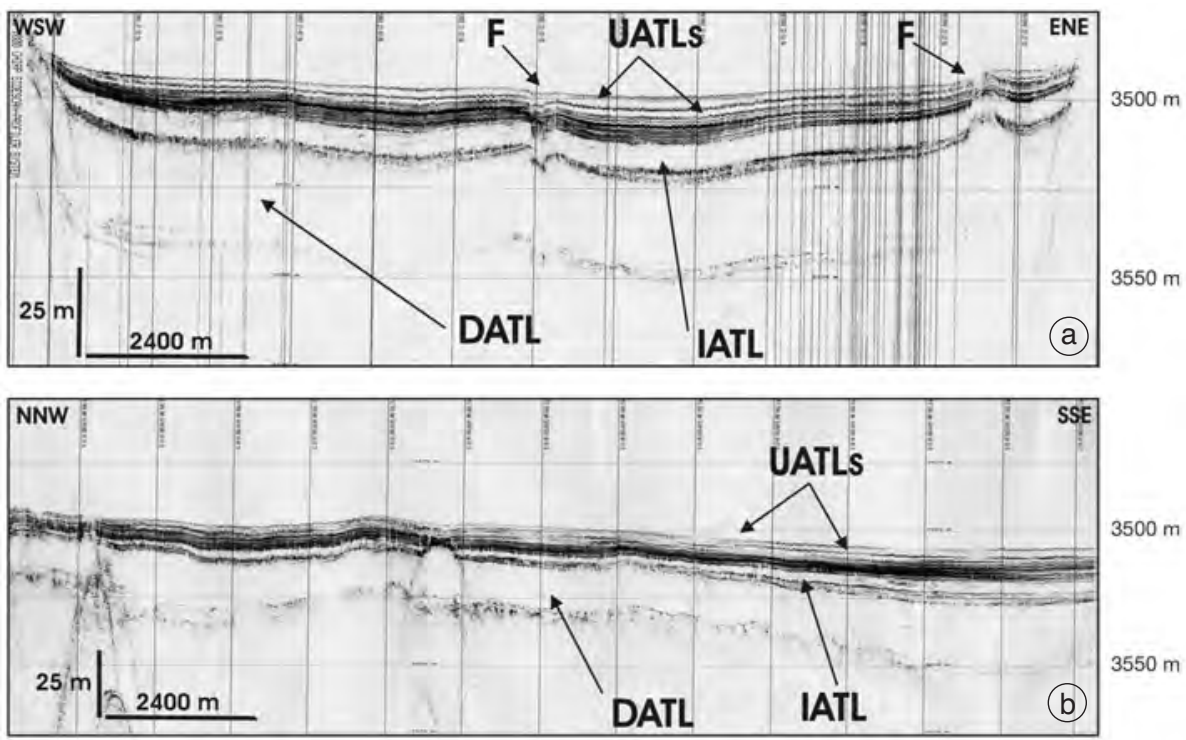

Fig. 7a,b. a) Chirp line of the Western Gortani Basin. b) Chirp line over the Eastern Gortani Basin. The deepest and the intermediate ATLs have a basin-wide distribution and can be correlated in the two basin sectors separated by the Gortani ridge (DATL - Deepest ATL; IATL - Intermediate ATL; UATLs - Uppermost ATLs; F - active fault). 
(a)
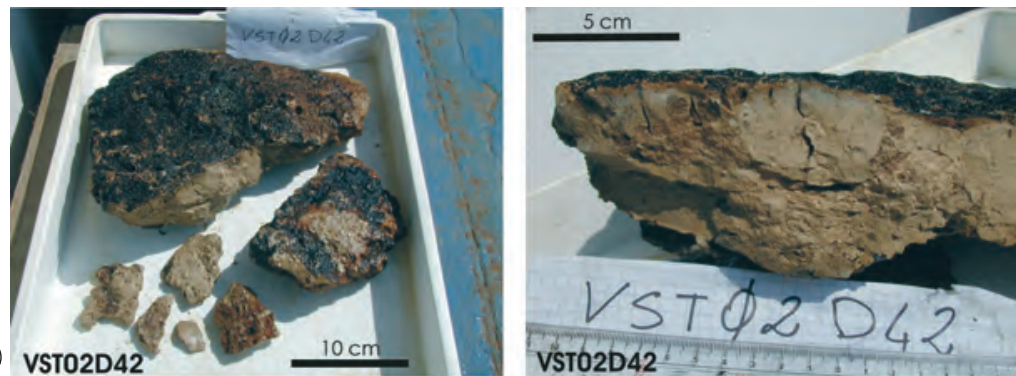

(b)
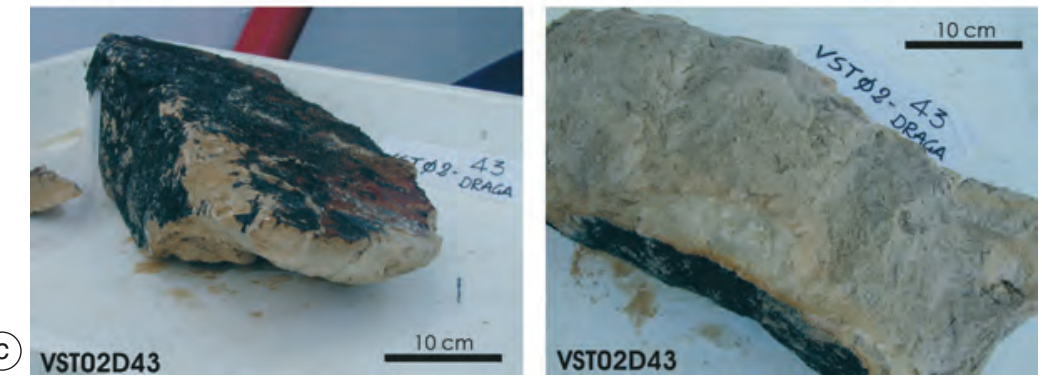

(d)

Fig. 8a-d. Selected samples of hardground crust paving some sectors of the Vavilov seamount: a) and b) from the southern flank; c) and d) from the southewestern flank.

(a)
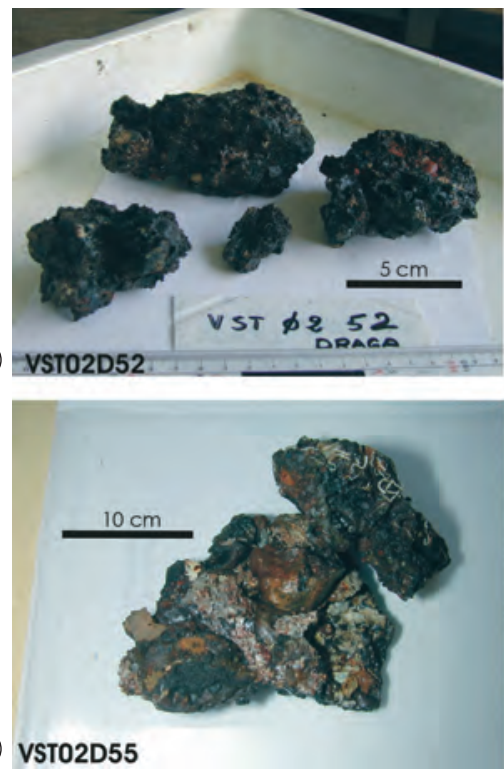
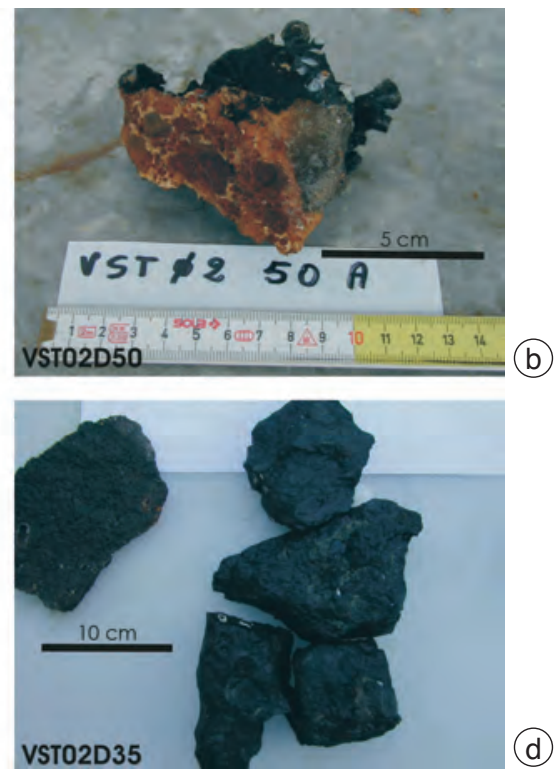

(d)

Fig. 9a-d. a) Explosive volcanic scoriae from the base of the southern axial summit of the Vavilov edifice: b) breccia sample from the upper western flank of the volcano; c) explosive volcanic scoriae from the northwestern Vavilov edifice; d) hydrothermal Mn precipitates. 
and $3200 \mathrm{~m}$ : three dredgings related to circular features with diameter of around $1 \mathrm{~km}$ (D28 and D30 on the same dredging transect; D29) and one dredging was attempted on ridges perpendicular to the slope of the edifice (D57); all dredges were recovered empty. The same result was obtained along the dredging transect D53, on the western base of the edifice, at a depth between 3100 and 2700. This can be possibly taken as evidence that even if the individual volcanic elements of the deep volcano flanks have a distinct morphologic expression they are however relatively old and presumably draped by sediments.

Three dredgings from the southeastern flank of the volcano, at depth between $3000 \mathrm{~m}$ and $2300 \mathrm{~m}$ (D42, D43, D44), recovered various types of carbonate crusts (hardgrounds). The carbonate crust recovered in site D42 displays a smooth upper surface, inferred to be exposed at the seafloor due to the presence of encrustant organisms, and of a pervasive black Fe-Mn oxides coating (fig. 8a); the lower surface is rough (fig. 8b) and no variations in the crust hardness are appreciable from the top surface toward the base (fig. 8b). The carbonate crust is mainly composed of small bivalve, gasteropod and pteropod shells within a fine grained matrix mainly consisting of foraminifer tests. Boring is intense with vertical traces, up to few centimeters in diameter, that cut the whole crust. In section, the colour is dull brown with small scale bioturbations evidenced by black stainings and thin lineations. Horizontal traces, with length up to $10 \mathrm{~cm}$ and diameter of $2 \mathrm{~cm}$, sometimes filled by an unconsolidated carbonate ooze, also occur along the lower surface of the crust. The carbonate crust of dredge D43 is $c a .15 \mathrm{~cm}$ thick; its upper portion is similar to D42 crust (fig. 8c) but its lower surface is not sharp and rather displays a transition between slightly cemented to soft foraminiferal ooze (fig. 8d). The carbonate crust recovered in D44 site is also similar to the D43 crust. These samples have been interpreted as carbonate hardgrounds formed under sediment-starved conditions. Such lithification appears to be pervasive along significan parts of the volcano edifice.

Dredgings D40, D45, D61 were carried out along the upper flank of the southern axial cul- mination of the edifice between 1700 and 1400 $\mathrm{m}$ depth. The only recovery was a thin veneer of mud sticking to the dredge D40.

Two seafloor transects were conducted on the upper portion of the western flank of the volcano between $2200 \mathrm{~m}$ and $1700 \mathrm{~m}$ depth. Dredging D52 was carried out to the south while dredging D49 and D50 were carried out along the same dredging line in the central area. Dredge D52 recovered a cemented sand, composed of highly oxidized foraminifera tests and black sand-sized volcaniclastic grains, together with four pieces of fresh, black glassy material with vesicles up to $1 \mathrm{~cm}$ in diameter. The largest glassy piece has dimension of $12 \times 8 \times 5 \mathrm{~cm}$ and displays a flat surface with scattered red mud blobs (fig. 9a). White gravel-sized clasts at times displying a pomi-ceous structure are embedded in the glassy samples. The glassy samples have been interpreted as scoriae produced by explosive activity in the upper portion of the submarine edifice; a similar genetic process can be the source of the volcaniclastic grains that make up the cemented sand. We also recovered thin, $c a .2 \mathrm{~cm}$-thick, hard carbonate crusts, with sharp and tabular upper and lower surfaces and abundant bioturbation. These crusts do not present broken margins and have circular or ellipsoidal shapes with dimension up to $15 \times 10 \mathrm{~cm}$ (fig. 10a). These samples are tentatively interpreted as carbonate nodules forming within unconsolidated sediments in response to localized lithification at or below the seafloor. D50 and D49, from the same transect, recovered pieces of a poorly sorted breccia and carbonate nodules, similar to those found in dredge D52. The breccia is composed by highly oxidized lava clasts with dimensions up to $5 \mathrm{~cm}$ floating within a micritic carbonate or sand clasts (fig. 9b).

Seven dredgings were carried along the topmost axial portion of the edifice from 1700 to $900 \mathrm{~m}$ depth. Two dredgings in the northern portion (D60 and 54) only collected unconsolidated mud with fragments of the solitary coral Desmophyllum cristagalli. On the northwestern side two dredgings, D51 and D33, resulted unproductive, while a large altered lava fragment was collected at station D48. In the same station, nodules similar to those found in dredge D49 and D52, were collected. Two lava samples were col- 
(a)
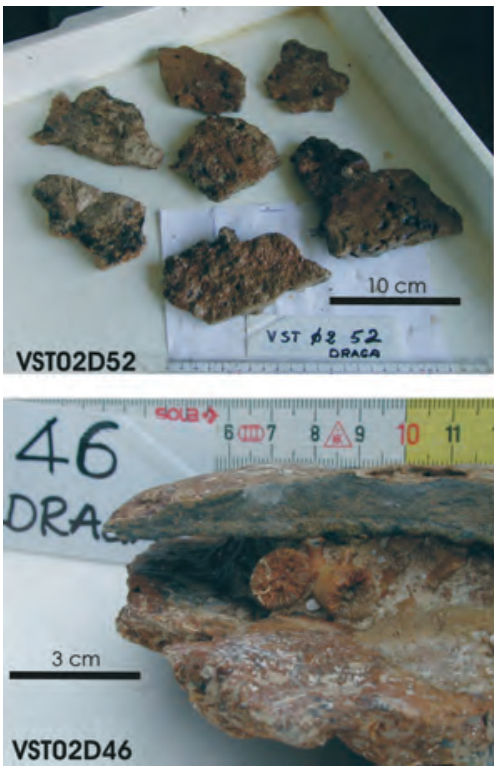
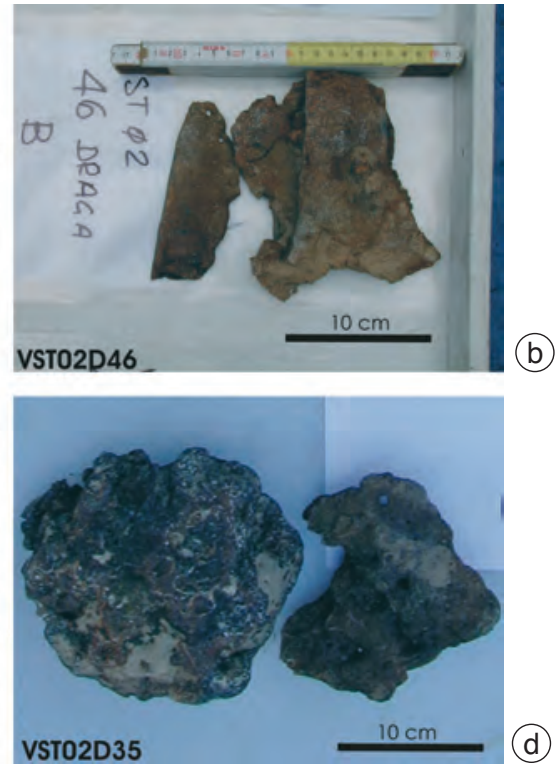

Fig. 10a-d. a), b), c), d) Selected samples (dredge station shown in figure) of carbonate nodules.

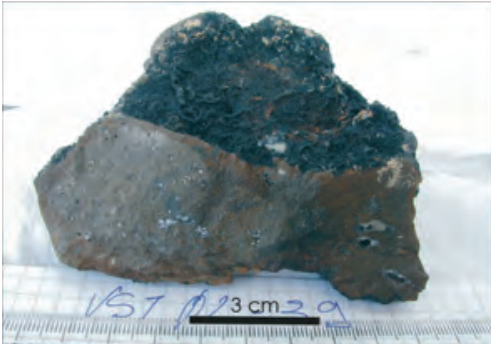

(a) VST02D39

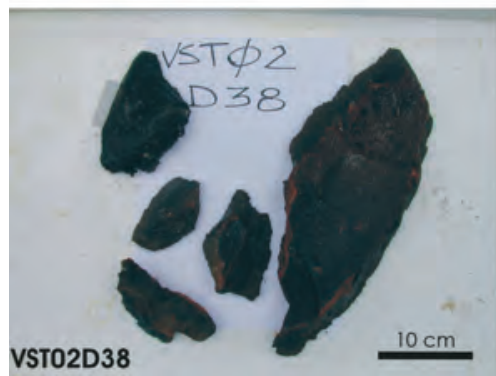

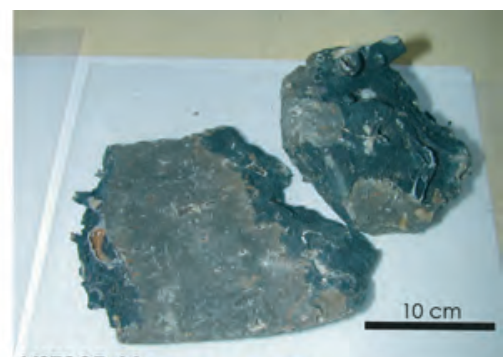

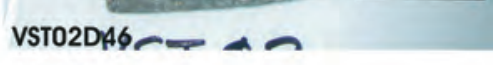

(b)

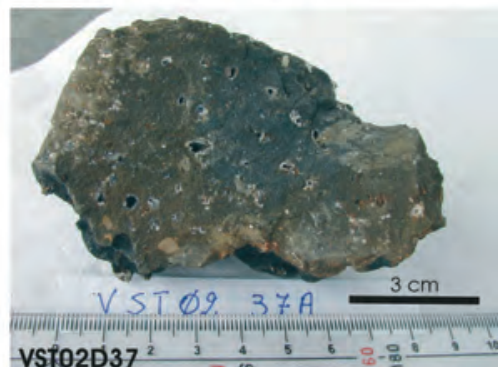

(d)

Fig. 11a-d. a), b), c), d) Selected samples of lavas (dredge station shown in figure). Note the highly altered appearence and the ubiquitous Mn coating of the samples. 
lected also in the southern portion (D32 and D39: fig. 11a). Dredging D39 recovered a scoria similar to that of station D52 suggesting that explosive activity recently occurred also along this portion of the submarine edifice. A framework of corals and serpulids cemented by a carbonate matrix was found associated with the lavas in dredges D32 and D39 and in D59. Furthermore, a hardground similar to those of station D44 was collected by dredging D59 from the eastern flank.

Eight dredges were collected on the northern axial culmination of the edifice. D34 and D27 carried out on a conical feature at depth between 1200 and 1000 collected framestones (fig. 12a). Lava fragments were collected both from the western (stations D35 and D46: fig. 11b) and the eastern flanks (D55). In addition, a volcanic scoria was collected at site D55 (fig. 9c).

Unconsolidated mud was collected on station D26, on the western side of the Vavilov, while framestones were recovered at station D41 and D36, from the other flank. Carbonate nodules were collected on dredges D35 and D46 (fig. 10b-d). Dredging D35 recovered also a thin soft Mn-crust with alternation of highly cemented laminae with metallic luster and more porous laminae with filamentous structure (fig. 9d). This sample is interpreted as evidence that hydrothermal activity occurred recently on the volcano.

Five dredgings were carried out on the northernmost part of the elevated axis of the volcano. D31 was empty; three dredgings recovered lava samples from the western side (D47, D38 and D37: fig. 11c,d). Thick hardground crusts, similar to those found in the deeper portion of the southern flank, were collected at stations D47 and D56. Framestones were collected by dredgings D47 and D37 (fig. 12b-d).

\section{Discussion and conclusions}

1) In the area of the Stromboli valley, we obtained evidence that some sediment-gravity (a)

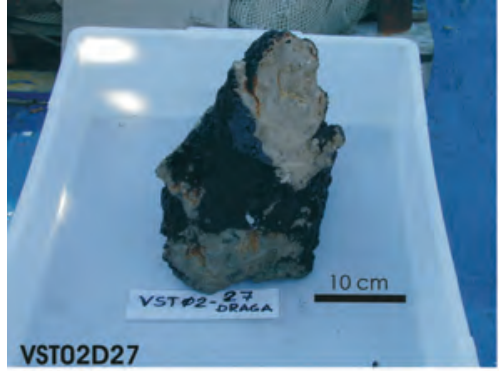

(C)

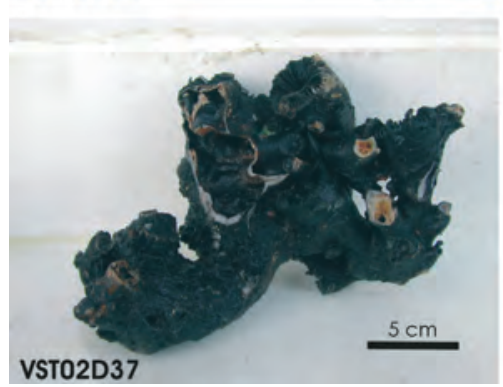

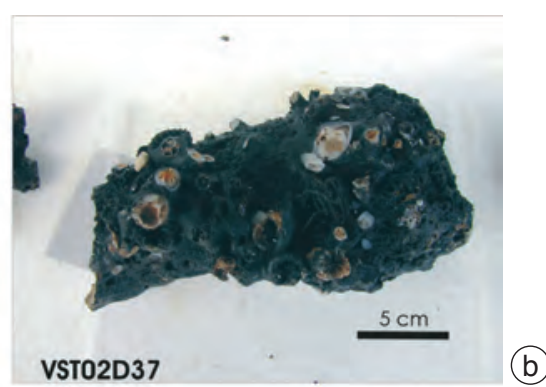

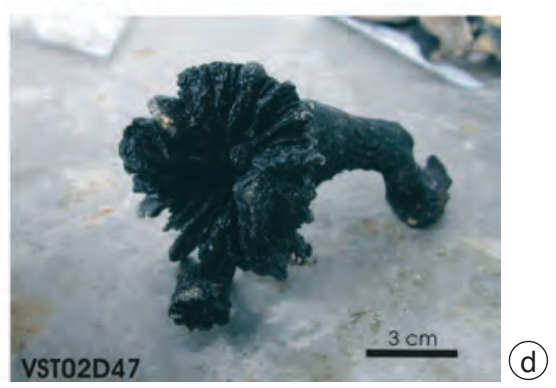

Fig. 12a-d. Selected samples of framestones. An evolution from corals d) and c) that are filled by sediments and then lithified b) and a) is envisaged for their formation. 
flows generated from the Sciara, are at times capable of surmounting the $200 \mathrm{~m}$ high northern margin of the canyon valley and depositing sediments in the adjacent slope. Although there is still uncertainty about the height of an obstacle that can be surmounted by a turbidity current as a function of flow thickness (Kneller and Buckee, 2000), flows with a minimum thickness in the order of $100 \mathrm{~m}$ are likely responsible for deposition as observed at site $\mathrm{C} 16$ site. This, in turn, poses important constraints on the events responsible for the initiation of those flows, that must be linked to the higher-energy processes affecting the submarine portion of the Stromboli flank.

2) The Marsili fan is channelized down to its distal part and lobes develop both in its central and distal parts. Inner thalwegs, longitudinal intra-channel bars, terraces and outer levees are the architectural elements that compose the channels. Preliminary interpretation of box cores indicate that the depositional style is mainly dominated by debris flow processes.

3) The recovery of still warm lavas and fresh scoriae from the Casoni seamount evidences that the present-day Stromboli magmaplumbing system triggers also submarine activity, both effusive and explosive at $c a .1000 \mathrm{~m}$ depth. Recent explosive activity is documented also for the Vavilov seamount, where fresh scoriae were found in numerous sampling sites, located preferentially along the top of the volcano. The combined evidence of Casoni and Vavilov seamounts indicates that explosive activity in the Tyrrhenian submarine volcanoes is a common process also at water depth in the order of $1000 \mathrm{~m}$. The freshness of the scoriae sampled from the Vavilov seamount markedly contrasts with the highly altered lava samples obtained from adjacent sites. This indicates that the recent volcanism of this submarine volcano occurs mainly through explosive activity. We hypothesize, for some centres of the Vavilov seamount, a scenario where a phase of effusive eruption is followed by the upwelling of a volatile rich magma, through the accumulation of gas bubbles below a volcanic plug and by the consequent triggering of volcanic explosions, as proposed for seamounts of the Mid Ocean ridge (Hekinian et al., 2000).
4) The recovery of fresh hydrothermal Mnprecipitates indicate that hydrothermal activity is still occurring in the Vavilov seamount.

5) In the deep flank of the Vavilov volcano, where dredging transects gave no results, the volcanic constructs are old and sediment covered even though they still have a morphologic expression. Submarine carbonate lithification is a widespread phenomenon occurring on the Vavilov seamount, as documented by the ubiquitous presence of carbonate crusts. Lithification occurring at or below the seafloor takes place under varying conditions leading to the formation of nodules, hardgrounds, and framework crust. A progression from nodule formation within unconsolidated sediments to thick hardground crust, growing from the seafloor downward and resulting in a pavement at the seafloor is envisaged. Once the seafloor is lithified or where volcanic rocks crop out, corals can grow on the hard substratum and build cemented framework crusts. These findings confirm that lithified carbonate crusts are frequent in areas characterized by sediment-starved conditions, as already recognized in the Mediterranean Sea and particularly in the Tyrrhenian Sea (Selli, 1970; Allouc, 1990; Remia et al., 2004).

6) Chirp investigation of the Vavilov Basin evidenced that its recentmost sedimentary infill mainly consists of thick acoustic transparent layers. Whatever the process responsible for the deposition of the ATLs, the seismic data suggest that the Vavilov Basin is affected by the same sedimentary processes that are active in the other deep abyssal plains of the Mediterranean Basin, where analogous seismic horizons have been recognized (Hieke, 2000; Rothwell et al., 2000). Finally, Chirp lines have shown that active faulting, with a NNE-SSW direction, affects the basin floor.

\section{Acknowledgements}

We thank Captain Nicolangelo Lembo, officers and crew of the R/V Urania. Thanks are also due to Andrea Argnani and Marco Taviani that helped in improving the quality of our paper. We are also grateful to Francesco Frugoni, editor of this volume. 


\section{REFERENCES}

Allouc, J. (1990): Quaternary crusts on slopes of the Mediterranean Sea: a tentative explanation for their genesis, Mar. Geol., 94, 205-238.

BerTAGNini, A. and P. LANDi (1996): The Secche di Lazzaro pyroclastics of Stromboli volcano: a phreatomagmatic eruption related to the Sciara del Fuoco sector collapse, Bull. Volcanol., 58, 239-245.

CAREY, S. (2000): Volcaniclastic sedimentation around island arc, in Encyclopedia of Volcanoes, edited by $\mathrm{H}$. SigurdSson (Academic Press, San Diego), 627-642.

Fretzdorff, S., M. Paterne, P. Stoffers and E. Ivanova (2000): Explosive activity of the Reuinion Islands volcanoes through the past 260000 years as recorded in deep-sea sediments, Bull. Volcanol., 62, 266-277.

Gabbianelli, G., C. Romagnoli, P.L. Rossi and N. CALANCHI (1993): Marine geology of the Panarea-Stromboli area (Aeolian arcipelago, Southeatern Tyrrhenian Sea), Acta Volcanol., 3, 11-20.

Gamberi, F., M. Marani, D. Penitenti and G. Dalla Valle (2002): Sedimentary dynamics off-shore Sciara del Fuoco from shallow-to deep-water, in Annual Meeting of Coordinated Project: Hazard Assessment of Stromboli Volcano, 17-19 September 2002, Stromboli.

Hekinian, R., F. Pineau, S. Shilobreeva, D. Bideau, E. GRACIA and M. JaVoY (2000): Deep-sea explosive activity on the Mid-Atlantic ridge near 34 $50^{\prime}$ : magma composition, vesicularity and volatile content, J. Volcanol. Geotherm. Res., 98, 49-77.

HiEkE, W. (2000): Transparent layers in seismic reflection records from the Central Ionian Sea (Mediterranean) Evidence for repeated catastrophic turbidite sedimentation during the Quaternary, Sed. Geol., 135, 89-98.

Hornig-KiarsgaARd, I., J. Keller, U. Kobersky, E. STADLBAUER, L. FranCALANCI and R. LENHART (1993): Geology, stratigraphy and volcanologic evolution of the island of Stromboli, Aeolian Arc, Italy, Acta Vulcanol., 3, 21-68.

KAstens, K.A. and J. MAscle (1990): The geological evolution of the Tyrrhenian Sea: an introduction to the scientific results of ODP Leg 107, Proceedings of the ODP, Sci. Res., 107 (College Station, TX, Ocean Drilling Program), 3-26.

KNeller, B. and C. Buckee (2000): The structure and flu- id mechanics of turbidity currents a review of some recent studies and their geological implications, Sedimentology, 47, 62-94.

KokeElaR, P. and C. Romagnoli (1995): Sector collapse, sedimentation and clast population evolution at an active island-arc volcano: Stromboli, Italy (1995), Bull. Volcanol., 57, 240-262.

Remia, A., P. Montagna and M. Taviani (2004): Submarine diagenetic products on the sediment-starved Gorgona Slope, Tuscan Archipelago, Chem. Ecol., 20, 131153.

Robin, C., P. Colantoni, M. Gennesseaux and J.P. ReHAULT (1987): Vavilov seamount: a middly alkaline quaternary volcano in the Tyrrhenian Basin, Mar. Geol., 78, 125-136

Rosi, M., A. Bertagnini and P. LANDi (2000): Onset of the persistent activity at Stromboli volcano (Italy), Bull. Volcanol., 62, 294-300.

Rothwell, R.G., M.S. Reeder, G. Anastasakis, D.A.V. Stow, J. ThOMSON and G. KAHLER (2000): Low sealevel stand emplacement of megaturbidites in the Western and Eastern Mediterranaean Sea, Sediment. Geol., $135,75-88$

SAVElli, C. (1988): Late Oligocene to Recent episodes of magmatism in and around the Tyrrhenian Sea: implications for the processes of opening in a young inter-arc basin of intra-orogenic (Mediterranean) type, Tectonophysics, 146, 163-181

Schneider, J.L, A. Le Ruyet, F. Chanier, C. Buret, J. FerRIERE, J.N. PROUST and J.P. RosSEEL (2001): Primary or secondary volcaniclastic turbidites: how to make the distinction? An example from the Miocene of New Zealand (Mahia Peninsula, North Island), Sediment Geol., 145, 1-22.

SELLI, R. (1970): Ricerche geologiche preliminari nel Mar Tirreno, G. Geol., 37, pp. 249.

Selli, R., F. Lucchini, P.L. Rossi, C. Savelli and M. Del MonTe (1977): Dati geologici, petrochimici e radiometrici sui vulcani centro-tirrenici, G. Geol., 42, 221-246.

TiBALDI, A. (2001): Multiple sector collapses at Stromboli volcano, Italy: how they work, Bull. Volcanol., 63, 112125.

WeIMER, P. (2004): Petroleum systems of deepwater settings, EAGE, Distinguished Instructor Series No. 7, pp. 470. 